\title{
Text Analysis Preposition of Metaphor in Deli Tale
}

\author{
Rosmawati Harahap
}

Universitas Muslim Nusantara Al Washliyah Medan, Indonesia

*Corresponding author email: rosmawatiharahap@umnaw.ac.id

\begin{abstract}
Regional culture that is threatened with extinction in Indonesia must be addressed with research and workshops; training on cultural outcomes using regional languages is a kind of cultural revitalization. Hikayat Deli is the work of the local speaking community of Medan or Deli; socializing in the archipelago since spoken and mandated. The saga has both dulce and utile elements. There are two intellectual traditions in studying literature, namely the "logical empiric" intellectual tradition. The hermeneutical tradition is used by literary reviewers to find the essential meaning of a text such as the saga of Putri Hijau. This research method is a qualitative descriptive method with a literary perception approach, that is, the literature reviewer uncovers the meaning behind the reality of literary texts who pay attention to the representation of the text in accordance with the perspective of the sociology of literature study. The research results will be obtained by identifying language styles and then analyzing metaphors such as figurative language stylistics in the Putri Hijau saga text. Lecturers or literature teachers, cultural and literary researchers covered the understanding of the Medan community that needed to revitalize the Putri Hijau saga by identifying its metaphorical texts with a semantic approach.
\end{abstract}

Keywords: Hikayat Putri Hijau, Metaphor, Revitalization

\section{INTRODUCTION}

Revitalization and optimal contribution to the people of Medan. Even though there is Hikayat Deli, it is still worth seeing its existence. At this time, we cansaga see the text from the Putri Hijau manuscript in the research document. The threat of extinction can be caused because the owner of the culture is not aware of what is contained in it. This must be overcome by research and workshops; training on cultural outcomes using regional languages is a kind of cultural revitalization. Hikayat is the work of the local language community in Medan or Deli; socializing in the archipelago since spoken and mandated. The Kingdom of Deli is superior to the Kingdom of Aceh. This was investigated by Kembaren [1], who reported in his thesis that the Hikayat of Sultan Deli's Kingdom was in the form of legends and historical stories (historiography). Researchers think that Hikayat Putri Hijau is the same as Hikayat Kingdom of Sultan Deli.

Historical texts of an area (historiography) which rely on studies from the aspect of legends, especially those that emphasize the birth of historical legendary figures, as far as the author's knowledge, have not been carried out. Moreover, the study of the legend made the text of the Sultan Deli Kingdom's Hikayat published in the term Hikayat Putri Hijau (HPH).

\section{LITERATURE REVIEW}

Hikayat comes from the Arabic word "Hikayyah", the story with wisdom. Ahmad [2] and Jassin [3] wrote the understanding of saga, namely in Arabic literary stories. Definition of saga according to Aini et al. [4], that means literature in the form of prose has a literary form of saga. The Malay nation is one of the nations that is rich in literary works. Apart from novels and short stories, there is still Aini et al. [4], who terms saga as a form of prose literature that presents fictional, historical, religious, biographical stories or a combination of them. Maybe there are still many of us who don't know the meaning of 
saga or the intrinsic elements of saga. Many of the functions of this saga include solace, encouragement and entertainment. One example of a famous saga that we might learn is the saga of Putri Hijau which originated from the land of Deli. Hikayat Putri tells the story of the toughness of a daughter or girl who is not easily deceived by the elite from Aceh. A princess who is committed to being confident not to love men carelessly or who is "pretentious" as told of the courage of men who fight in a war to win the beauty of Princess Hijau. This raises the dignity of women who are considered weak and must surrender to men's orders. In addition to raising or presenting this saga religious learning, it can also arouse the spirit of the next generation to imitate the spirit of struggle shown by feminism. Saga has an intrinsic element and an extrinsic element. The intrinsic elements of the saga are in the form of theme, plot, characterization, point of view, language style, and message (for a more complete explanation, see here only). While the extrinsic element of the saga is in the form of the author's history, socio-culture, customs or values contained in society.

Hikayat Putri Hijau has been studied philologically by Irwansyah in 2011, lecturer at the Faculty of Cultural Sciences at USU Medan. There are still students who can synchronize Hikayat Putri Hijau.

\subsection{Indonesian Literature during the Sultanate of Islam (XII to XVII Century)}

At first, the stories circulating were related to the stories of the prophets, Rasulullah Muhammad SAW, Sunan, Wali, or other holy people [5]. However, this Islamicinspired literature continues to develop into a life with an archipelago background such as the suluk Wujil written by Sunan Bonang. Telling Sunan Bonang's discourses to Wujil, a learned midget, a former servant of the Majapahit palace.

Indonesian literature during the Sultanate of Islam was marked by the emergence of translations and adaptations of Arabic and Persian works into Malay. This chapter coincided with the emergence of two Islamic kingdoms, namely Samudra Pasai (1270-1516 AD) and Malacca (1400-1511 AD). Indonesian literature during the heyday of the Islamic Sultanate was also marked by the awareness of Malay authors to put their own names in the essays they wrote. Sufism poetry and other works of mystical style were born during this period, as were more original epics, historical works, and romances. The originality of the work of a Malay writer appears to be the beautiful and profound poetry of the Sufism Hamzah Fansuri [6]-[7].

North Sumatra actually also keeps a big story in the course of Indonesian literature in the pre-colonial Islamic Sultanate apart from the origin of the Baros descent as found by Djamaris. This great story is even written in the Pararaton Book, which considers Gajah Mada to write down the existence of a large kingdom in North Sumatra, namely Haru. The existence of this Haru Kingdom is already written on the internet site. Darmawijaya [8] compiled the "Sultanate of Islam Nusantara" failed to mention the greatness of this Haru Kingdom. Likewise, Marco Polo, who carried out an expedition in 1292, did not mention the name of this Haru or Aru Kingdom. Marco Polo only indicated that there were eight kingdoms on the island of Sumatra, where the entire population was idolatrous. Marco Polo visited Sumatra Island to coincide with the formation of the first Islamic port states. Some of the kingdoms he mentioned were Ferlec (Perlak), Fansur (Barus), Basman (Peusangan)-in the present-day Bireuen area-, Samudera Pasai and Dagroian (Pidie). The other three kingdoms are not mentioned. Another source adds Lambri (Lamuri) and Battas (Batak).

In this opportunity, I will give a glimpse of the glory of the Haru Sultanate which I got from Reid in 2010. Haru first appears in the Chinese chronicles of the Yuan dynasty, where Kublai Khan demanded the submission of the Haru ruler to China in 1282, which was responded to by sending tribute by the brother of the ruler of Haru in 1295. Islam entered the Haru kingdom at least in the 13th century. It is possible that Haru converted to Islam earlier than Pasai, as mentioned by Sulalatus Salatin. While the population is still not all-embracing Islam, as notes d'Albuquerque (Afonso de Albuquerque). Also, in Mendes Pinto's notes in 1539, it was stated that the people of 'Aaru' on the northeast coast of Sumatra and visiting their Muslim king, about twenty years earlier, Duarte Barbosa had recorded about the Aru kingdom which was then controlled by pagan cannibals. However, there is no statement of cannibalism in Chinese sources at that time.

In the 16th century Haru was one of the important powers in the Strait of Malacca, apart from Pasai, Portugal which in 1511 controlled Malacca, and the former Sultanate of Malacca which moved its capital to Bintan. Haru established good relations with Portugal, and with their help Haru invaded Pasai in 1526 and massacred thousands of its inhabitants. Haru's relationship with Bintan was better than before, and Sultan Mahmud Syah married his daughter to the king of Haru, Sultan Husain. After Portugal expelled Sultan Mahmud Syah from Bintan in 1526 Haru became one of the strongest countries in the Malacca Strait. The archaeological remains in the City of China show that the Haru region has trade relations with China and India. However, in Ma Huan's record, unlike Pasai or Malacca, in the 15th century Haru was not a large trading center. It seems that this kingdom was unable to compete with Malacca and Pasai in attracting traders who had previously been active in visiting China. The Haru kings then turned their attention to piracy. Haru adopted the Malay custom, and in Sulalatus Salatin the elders used Malay titles such as "Raja Pahlawan" and "Sri Indera". However, this adoption of Malay adat may not be complete, and elements of non-Malay adat (Karo) are still present. The list of kings who ruled in Haru, including: Sultan Husin, Sultan Mansur Shah (1456-1477), and Sultan Ali Boncar. That said, the former Haru Kingdom was located in the City of Rantang and the City of China (Hamparanperak). 


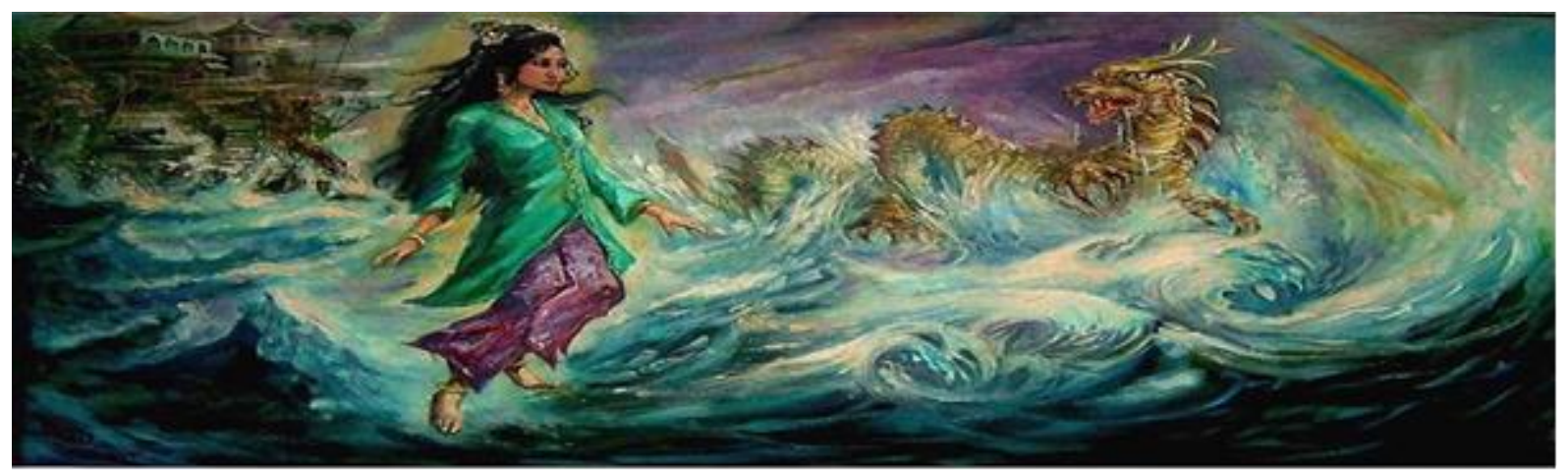

Figure 1. Putri Hijau Illustration

\subsection{The Deli Malay Version of the Putri Hijau Hikayat Manuscript}

Before reading the Hikayat Putri Hijau, consider the following picture. The term daughter comes from the Sanskrit word meaning 'girl'. Green princess means a princess who is always synonymous with green.

Putri Hijau is very beautiful but can not be described in paintings if expressed in words orally. Unmatched verbal rather than nonverbal beauty. UMN Al Washliyah student Anri Ayu Kartika Sari Semester 3C admits that Putri Hijau is prettier than herself. The beauty of Malay girls should not be equated with the beauty of Turkish women. Riris Ramadani said shyly that Putri Hijau was prettier than herself too. The conclusion is that the Green Princess is very beautiful.

Now the main source that allows the acquisition of the Hikayat Putri Hijau (HPH) manuscript. Putri Hijau is a figure in a classic legend in the Labuhan Deli area, Indonesia. The history that contains the story of events in the 15th and 16th centuries is the bloodiest period in the lowland zone of Aceh, East Sumatra, and the Malaysian peninsula. Four kingdoms slaughtered, conspired, and conquered each other to gain power in the international trade zone which is now known as the Malacca Strait. In the midst of the struggle for economic cake, on the banks of the Deli river - about $9 \mathrm{~km}$ from Labuhan Deli to be precise - a classic legend was born named Puteri Hijau. The legend of the Princess, which is always depicted with all beauty vocabulary, has survived until now in two versions. The first version comes from historical records that are similar to oral stories that developed in the Deli Malay community. The second version is the saga of the Karo people. The two are contradictory and seem to be competing with each other to highlight the identity and ego of their respective tribes.

\subsection{Conceptual Metaphors}

The origin of the word which comes from Greek is the meta 'part' phora 'form'. Speakers communicate with words whose meaning is conceptual metaphors, which is a cognitive process of expressing a concept with another concept, which corresponds to the previous concept, to understand or compile. The principle of the metaphor is in accordance with the constructivism view of learning. With metaphors, abstract concepts can be built from concrete things that are close to student experiences. How complex mathematical ideas can be constructed and how these ideas are. Metaphor is the use of words or groups of words, not with their true meaning, but as a painting based on similarities or comparisons. A concept is an abstract idea used to classify or classify a set of objects. Conceptual metaphor is a cognitive process of expressing a concept with another concept, which corresponds to the previous concept, to understand or construct a more abstract concept. The formula for the metaphor of the concept: $\mathrm{A}=\mathrm{B}$, but $\mathrm{B}=$ does not mean denotative. The meaning of the word that is explained directly refers to the object or its condition, which is the lexical or denotative meaning of the word with a more concrete example. Metaphor comes from the meta words "part" and phora "form". The ideas contained in A are only partially covered in B.

\section{METHODOLOGY}

\subsection{Research Method}

To make it easier to obtain objective data and conclusions about the analysis of the prepositional metaphorical text in Hikayat Hikayat Putri Hijau from the type of metaphor, the steps taken by the researcher is to conduct a literature study that identifies the selection and relevant variables through the content analysis method. Content analysis is a study that is in-depth discussion of the content of written or printed information in the mass media [9]-[11]. The pioneer of content analysis is Harold d. Lasswell, who pioneered the symbol coding technique, which is a symbol or message systematically, then given an interpretation. This research uses content analysis techniques and semiotic qualitative analysis. 


\subsection{Data collection technique}

The data collection technique that the researcher used to obtain data and information about moral values is by using Library Research or library research. As a data collection technique. In the book entitled Research Methods suggests that library research is a technique of collecting data by reviewers studying books, literature, notes and reports that have to do with the problem being solved.

The steps taken by the author in data collection techniques are as follows.

1. Read the whole story of Putri Hijau.

2. Understand the content of the Putri Hijau saga that has been read and is closely related to the problem of figurative meaning.

3. Analyze paragraph by paragraph, chapter by chapter, and perform classification.

\subsection{Data source}

As for the source of the first data in this study is the manuscript typed Hikayat Putri Hijau author Dada Meuraxa.

\subsection{Data analysis technique}

Analysis is basically a way of dividing an object into its components. Data analysis techniques are a form of work and systematic steps in research work. In the analysis of data that has been read, it is treated carefully and carefully and systematically based on the problems raised. An object can be performed if the object has a structure, which consists of a number of components. Researchers analyzed the data contained in the manuscript. Data analysis is the process of arranging the order of the data and organizing it in a pattern, categorization and basic unit description. The data analysis here is using descriptive analytic. The limitation only revolves around the text category in the Hikayat Putri Hijau saga using the meaning of the ladder which includes an index.

\section{RESULTS AND DISCUSSION}

In previous research, it has been detected that metaphors are direct comparative figures, namely comparing something directly to its substitute. In another sense, metaphorical figure is the use of words or groups of words that do not actually mean, but rather as paintings based on similarities or comparisons. The characteristic of this figure of speech is the use of figurative words and there is a choice of words that equate something with something else. Studies of metaphors as a language style [12]-[15].

\subsection{Identification of Metaphorical Texts in the Story of the Hikayat Putri Hijau}

From the Putri Hijau saga analyzed, there are 5 points on pages $7,9,34,39$, and 52 as shown in the quotation below. "The empress also began to conduct an investigation, at first the empress asked the ladies and gentlemen of the caregiver, if her daughter was playing in love with the hulu balang and the palace guards," (page 7, paragraph 1). In this quote, it can be seen that the empress wants to know what the Princess is doing in the palace by asking the host nurse and the ladies-in-waiting without the Princess knowing. This shows how the empress wants to know the things that Princess Hijau does every day outside the empress's supervision. "What the hell made it," thought Datuk Sunggal "Datuk Sunggal approached the empress and chatted just to raise the spirit of the empress," (page 9, paragraph 1). The curiosity depicted in the above quotation is how the king wanted to know why the empress lately was so pensive and not as cheerful as usual.

So, the king asked the empress directly to find answers to the curiosity he was thinking by chatting directly with the empress. "The king said to Putri, asking her whereabouts and the reason why she lived alone in the middle of the jungle," (page 34, paragraph 2). The king wanted to know the origin of the Princess by asking directly to the Princess, why did the Princess come to be in the middle of the forest alone like this. Isn't it right that no one is in this wilderness, let alone a woman. "Is there a lack of caregiver service? Putri still does not answer, only nods are visible," (page 39, paragraph 2). The king asked Putri directly whether there was a bad caring host service. The king wanted to know how the caretakers worked, whether according to the king's orders or not. "To find and prove the truth of the hulubalang story, another commander was sent accompanied by the guard as a guide," (page 52, paragraph 2). To prove the hulubalang's words, the king ordered other commander-in-chiefs to prove the truth stated by the first commander. It seems that the king wanted to know the truth conveyed by the first commander. Do hulubalang say honestly or just make up stories that are not true about the Princess they saw.

The five quotes above all describe the curiosity seen from the words "Conducting an investigation, what is it, asking the origin, caring host services, and proving the truth". This understanding is supported by the opinion of Kansil and Christine (2011), which states curiosity in the form of attitudes and actions that always seek to know more deeply and broadly from something they have learned, seen, and heard. "The Empress was sad to see this incident, after knowing that Putri had never cheated on anyone," (page 8, paragraph 1). Here it can be seen that the empress also feels what Putri Hijau feels. This is supported by Hansen in Asri (2008), who says empathy is a sense of trying to understand another person's condition as that person understands it in conveying that understanding to him. The king also felt what Putri felt seeing what happened to the Princess and the king also 
gave a sense of empathy not only with feelings but expressed in language. This is supported by Carkhuff's opinion in Asri (2008), which states that empathy is the ability to know, understand and feel other people's feelings with verbal expressions and behavior, and communicate this understanding to others. In the Putri Hijau saga religious values are found on pages 8, 10, 25, and 47 as in the following quote.

"Maybe it has the will of the Almighty, thought my beloved mother," (page 8, paragraph 1).

"With a calm mind, the empress surrendered to God," (page 10, paragraph 1).

"Step, fortune, meeting, death, God determines it. Humans just pray and try," (page 25, paragraph 2).

"Only Allah determines it. If death calls, no one can hold it back," (page 47, paragraph 2).

In the four quotes above, it can be seen how the empress surrendered to God for the pregnancy experienced by the Princess and the empress acknowledged that there was a wisdom behind what happened to Putri Hijau. The above statement has more religious value, which can take the form of three types, namely: (a) the analogous value of certain scriptures, (b) religious values that are born from divine consciousness or instincts which do not refer to one religious teaching so that it is more of a value in nature. universal values, (c) to preach for certain religions [16].

\subsection{Metaphor Analysis}

1) "The empress also began to investigate, at first the empress asked the ladies and gentlemen, if her daughter was playing in love with hulu balang and palace guards."

2) "That's the difficulty of weighing and deciding punishment. The first thinks about the legal basis and the second thinks about justice, the third thinks about considerations, the reasons for muhasabab and others." (page 18, paragraph 1).

3) "For Datuk Sunggal, perhaps only the first one that encouraged him to be brave and have the heart to impose the punishment, because of the legal basis he holds." (pages 18, paragraph 2).

4) "And finally, it was sufficient the count of seven commander-in-chiefs, that the journey had passed for seven days and seven nights." (page 23, paragraph 3).

5) "And she was in the middle of the forest, because she was sentenced to throw away by her father and because she was pregnant and did not know what and who caused it." (page 35, paragraph 1). "Then report the actual situation as seen by the first commander." (page 52, paragraph 2).

6) "The king also laughed, while the jokes that relieved fatigue were over, so that was the place where the rabbit ordered the king to finish. Such is the intimacy between the people and their king." (page 29, paragraph 2).

7) "Seeing that his guards and commander were successful in hunting, the king said," You are successful, apparently.” (page 29, paragraph 1).
8) "Hurriedly the king climbed up the tree post. He tried several times but it also slipped downward." (page 34, paragraph 1).

9) "Forgive my lord, sorry please build a ladder for my master first." (page 34, paragraph 1).

10) "After the king of Aceh could not defeat Delitua with the strength of his original soldiers, deception was changed. A strategy to retreat, then go back forward." (page 57, paragraph 3) is installed. They retreated to the Maimun Palace along the Deli River; It is seen that how the king thought creatively to make accurate tactics to defeat King Delitua which was unthinkable by others.

11) "So, like it or not, the king of Delitua and Putri Hijau stepped aside along with several soldiers and hulubalangs who were loyal to resign so that the king of Aceh would not be caught." (page 59, paragraph 2).

\section{CONCLUSION}

In this paper, a research has been conducted on the analysis of metaphorical prepositional texts in Deli Tale. Based on the results of the analysis, it can be concluded that by identifying language styles, and then analyzing metaphors in the form of figurative language styles in the text of the Putri Hijau saga, lecturers or teachers of literature, cultural and literary researchers, who cover the understanding of the people of Medan, see it is very important to revitalize the saga of Putri Hijau. by identifying the metaphorical text with a semantic approach. Training and socialization about culture using local languages is one form of cultural revitalization.

\section{REFERENCES}

[1] M. M. Kembaren, Hikayat Keturunan Raja Negeri Deli: Kelahiran Sebuah Legenda Sejarah. Tesis Doktor Falsafah. Penang: Universitas Sains Malaysia, (2011).

[2] S. Ahmad, Parama Sastra Indonesia. Medan: Deli, (1975).

[3] H. B. Jassin, Kesusastraan Indonesia Modern dalam Kritik dan Esai IV. Jakarta: Gramedia, (1985).

[4] N. N. Aini, N. Aprianti, Y. Ahmadi F., Upaya Meningkatkan Kemampuan Menulis Unsur Intrinsik Hikayat dengan Menggunakan Metode Cooperative Script di Kelas X SMK. Parole (Jurnal Pendidikan Bahasa dan Sastra Indonesia), 2 (5) (2019), 715-724.

[5] Md. S. Islam, S. Bt. Samsuddin, Moral Approaches and Roles of Prophet Muhammad (S.A.W) In Empowering Persons with Special Needs. Australian Journal of Basic and Applied Sciences, 12 (6) (2018), 30-35. 
[6] S. Ni'am, Hamzah Fansuri: Pelopor Tasawuf Wujudiyah Dan Pengaruhnya Hingga Kini di Nusantara. Episteme, 12 (1) (2017), 262-286.

[7] M. Ahsin, Interpretasi Sufistik atas Hadis Melalui Sastra dalam Syair Perahu Karya Hamzah Fansuri. Jurnal Studi Ilmu-Ilmu al-Qur'an dan Hadis, 21 (1) (2020), 193-216.

[8] Darmawijaya, Kesultanan Islam Nusantara. Jakarta: Pustaka Al-Kautsar, (2010).

[9] M. Bengtsson, How to plan and perform a qualitative study using content analysis. NursingPlus Open, 2 (2016), 8-14.

[10] C. Erlingsson, P. Brysiewicz, A hands-on guide to doing content analysis. African Journal of Emergency Medicine, 7 (3) (2017), 93-99.

[11] M. R. Roller, A Quality Approach to Qualitative Content Analysis: Similarities and Differences Compared to Other Qualitative Methods. FQS, 20 (3) (2019), 21 pages.

[12] F. Zhang, J. Hu, A Study of Metaphor and its Application in Language Learning and Teaching. International Education Studies, 2 (2) (2009), 77-81.

[13] A. L. Hasibuan, Metafora dalam Naskah Melayu Lama: Identifikasi Jenis-Jenis Gaya Bahasa Metafora dalam Syair. Laporan Penelitian Mandiri. Medan Pascasarjana Tanpa Penerbit, (2013).

[14] H. T. D. Ha, Metaphorical Language in Second Language Learners' Essays: Products and Processes. A thesis submitted to Victoria University of Wellington, (2015).

[15] Nurhaida, L. Marlina, An Analysis of Figurative Language in Views (Opinion Column) of Online Padang Ekspres Newspaper. E-Journal of English Language and Literature, 6 (2A) (2017), 44-52.

[16] A. Purba, Sastra Bangsa Kita. Medan: USU Press, (2008). 